\title{
Design of E-Public Service in Realizing Agile Government \\ Based on Information Technology: \\ Case Study in Indonesia
}

\author{
Dyah Mutiarin ${ }^{1}$, Ririn Sudiro' ${ }^{2}$ Misran $^{3}$ \\ 1,3 Master of Government Affairs and Administration, Universitas Muhammadiyah Yogyakarta, \\ Yogyakarta, Indonesia (email: mutiarin@umy.ac.id) \\ ${ }^{2}$ Public Administration, Universitas Muhammadiyah Yogyakarta, Yogyakarta, Indonesia
}

\begin{abstract}
E-Public services based on information technology have been improved during the industrial revolution 4.0. Implementing E-Public Service leads to transforming public services in government from the old designs to the new designs that can assist in realizing agile government models. The agile government model is a model of government that creates a culture of agile and intelligent bureaucracy. This model focuses on the requirements of speed and ease in government processes, including public services. This study aims to explain the design of e-Public Service in realizing the Agile Government model. This study uses a qualitative descriptive approach assisted by NVivo 12 software in processing data. This study shows that the design of public Service in realizing an agile government model based on information technology is creating responsive public services, facilitating and accelerating the process of public services, and improving the quality of effective and efficient public services
\end{abstract}

\section{Keywords:}

e-public service; agile government; information technology; Indonesia

\section{Introduction}

The concept of e-government is a way for the government to use new technology to comfortably serve public access to information and government services, improve service quality, and provide greater opportunities to participate in democratic processes and institutions(1Universitas 2019). e-Government is concerned with the delivery of government services to the public through an integrated and operable network of legacy systems, enhanced with the latest technology. Overall, e-Government requires the use of Information and Communication Technology (ICT) by the government in the provision of public services (Joseph 2017). 
The application of e-Government includes, among others, the interests of services that lead to the transformation of public services in government from old designs to new designs. According to Rowley the term electronic services (short for electronic services) or egovernment services can be interpreted as: "actions, efforts or performance whose delivery is mediated by information technology (including web, information kiosks, and mobile devices). The e-service includes elements of e-tailing services, customer support and service, and service delivery.

E-Government-based public services are one of the government's efforts to improve public services. With the existence of e-government-based public services, the needs of the community in various fields can be met (Ramdani 2020). Technological developments create innovations in public services. The application of public services can be done digitally so that public services can be applied effectively and efficiently. According to Ramdani, many public service innovations have been carried out by the government, both central and local governments, both on a macro scale to a micro-scale, starting from the creation of public service malls such as in Banyuwangi to micro matters in the form of digitizing services that do not need to be needed. face-to-face service (Ramdani 2020).

Public services based on Information and Communication Technology (ICT) are not only a demand for technological developments, but e-Public Services are also very much needed by the community. With e-Public Services, the government can implement effective and efficient public services. This effective and efficient public service can be linked to the agile government model. The agile government model is a government model that creates a bureaucratic culture that is alert, agile, and intelligent. This model focuses on the requirements for speed and convenience in the government process, including public services. The application of e-Public Service in an agile government model can be packaged for the benefit of public services such as population administration services, tax services, or health services based on Information and Communication Technology (ICT).

Thus, public services have become the center of attention of the government and society at the same time, in the last two decades. Public services that are fast, efficient, and in line with public expectations will be achieved with the help of information technology. Public services in the era of the industrial revolution 4.0 have the characteristics of all information technology-based services or what is often referred to as e-public services. "Internet of Things" 
has encouraged automation of registration in all fields, such as education, economy, society, and politics (B. Mokone, T. Eyitayo, and Masizana- Katongo 2018).

E-Public Service not only has the advantage of facilitating and accelerating the process of public services and improving the quality of effective and efficient public services but also empowering the community through distribution and transparency in decision making. According to Yusuf for the public sector to innovate is a demand for accountability, transparency, and various principles of good governance that lead public organizations to perform higher.

E-Government and e-Public Services have long been implemented in various provinces, including in West Java Province. Based on the results of the Provincial Level eGovernment Indonesia conducted by the Ministry of Communication and Information Technology, it was identified that at the start of the 2012 assessment West Java Province occupied the first position while in 2015 it fell to the second position after DKI Jakarta Province. West Java Province has 3 (three) superior public service innovations based on Information and Communication Technology (ICT), namely the first, online tax service innovation (Sambara Application), second about innovation in digital coffee seed distribution (Sibulubabeh), and third about the program economic empowerment of Islamic boarding schools (OPOP).

Of the three leading e-public service innovations above, the authors are interested in researching application-based online tax service innovations in West Java. This online tax service innovation is an innovation that can speed up and make it easier for people to pay Motor Vehicle Tax to be on time wherever and whenever. With this online tax payment, people don't have to worry about being late paying taxes and don't have to come to the SAMSAT office to queue.

\section{Basic Theory}

\section{Information and Communication Technology}

Technology is the knowledge that is aimed at creating tools, processing actions, and extracting objects. The term "technology" is widely known and everyone has their way of understanding technology. Technology is used to solve various problems in our daily lives, 
in a nutshell; we can describe technology as a product, process, or organization (Dan et al. 2018).

Meanwhile, according to Kistanto, there are three meanings of the word information. The first is information as a process, which refers to activities to become informed. The second meaning is information as knowledge (Ati et al. 2014). Here, information refers to all occurrences in the world (entities) that are infinite, untouchable, or something abstract. As something abstract, information is seen from the meaning contained in the entire medium used, then it can be interpreted differently between the sender and the receiver. Information is considered an abstract part of the human mind according to the content and meaning of the message received.

The third meaning is that information is considered as a real object or presentation of knowledge. As a real object, information is seen from a series of symbols and can be captured by the human senses and can be exchanged. Information is considered as real raw materials, which are outside humans which require further processing.

William \& Sawyer defines that information technology as a technology that combines computers with high-speed communication lines, which carry data, voice, and video. The concept of information technology is the most important public discourse of the world community in the 21st century because it is suspected that various world-scale changes are spurred by the presence of information technology, whose practice is supported by telecommunications technology and media technology in a unified communication technology system. Information and Communication Technology is the application of knowledge and skills used by humans in distributing information or messages to help solve human problems (social activities) to achieve communication goals (Setiawan 2018).

\section{E-Government}

Electronic Government is a government system process using ICT (information, communication, and technology) as a tool to facilitate communication and transaction processes to citizens, business organizations, and between government agencies and their staff. So that efficiency, effectiveness, transparency, and government responsibility to society can be achieved (Atthahara 2018). 
e-Government is concerned with the delivery of government services to the public through an integrated and operable network of legacy systems, enhanced with the latest technology. Overall, e-Government requires the use of Information and Communication Technology (ICT) by the government in the provision of public services(B. Mokone et al. 2018).

According to Putra, there are 6 benefits of e-Government, namely (Bahruni et al. 2018).

1. E-Government increases efficiency. ICTs help increase the efficiency of mass processing tasks and public administration operations. Internet-based applications can store data collection and transmission, as well as provide information and communication with customers. Significant future efficiency is achieved through the process of sharing data between governments.

2. E-Government improves services. Adopting a customer focus is at the heart of the current reform agenda. Successful service is built on understanding customer needs. Customer focus implies that users do not need to understand government structures and relationships to interact with the government. The Internet can help achieve this goal by bringing governments into integrated organizations that provide seamless online services. As with all services, E-Government services must also be developed based on user demand and value.

3. E-Government helps achieve specific policy outcomes: ICTs can help stakeholders share information and ideas, and then contribute to determining policy outcomes.

4. E-Government contributes to economic policy objectives: E-Government helps reduce corruption, promotes openness and trust in government, and contributes to economic policy goals.

5. E-Government is a major contributor to reform: The majority of countries face problems of modernization and public management reform. Current development means the reform process must be sustainable.

6. E-Government helps build trust between Government and citizens: Building trust between government and citizens is fundamental to good governance. 


\section{Agile Government}

An agile government is a government that can act flexibly, adaptively, and quick in responding to public problems (Joseph 2017). In practice, agile government (Agile Government) displays four characteristics, namely responsiveness, strategic adaptation, focus on results, and management of anticipating future problems (Reid 2020).

The agile approach to the organization was initially used by the information technology (IT) industry two decades ago. Agile methods and practices are used to overcome problems often faced by the IT industry, namely budget overruns, unfulfilled deadlines, low-quality output, and customer dissatisfaction (Amalia 2020) According to Denning, the agile mindset consists of (Bartakova et al. 2017):

1. Goals, attitudes, and values are focused on adding value and innovation for users and customers, not on short-term gains.

2. Managers see themselves as part of the team and act as drivers, not controllers so that they can take full advantage of employees' capacities and talents.

3. Forming autonomous and networked teams to operate complex and important tasks on a large scale.

4. The coordination mechanism uses structured, repeatable, and customeroriented practices.

5. Routinely realizing the value of transparency and continuous improvement of products, services, and work methods;

6. Communication is conducted in an open and two-way manner, not top-down and hierarchical.

7. Physical workspaces that are designed to be open, egalitarian, and encourage collaboration.

\section{E-Public Service}

The E-Service concept is a leading application by leveraging the use of information and communication technology (ICT) in different areas. Even though researchers have different meanings, they agree that technology has a role in facilitating the delivery of a service (Pada et al. 2016). According to Mualidin in e-Service, employees are involved in the interface, mediated by the Internet(Mualidin 2017). In addition, during an e-Service meeting, customers are limited to hearing and seeing, in traditional services, customers can experience the service 
using all of their senses. In addition, traditional services are limited by distance and opening hours, whereas e-Service has substantially removed these barriers.

E-Service or e-Public Service, which is a necessity for urban communities in particular, of course, has benefits contained in it. There are several benefits to E-Service, some of which are:

1. Access a larger customer base

2. Expanding market reach

3. Lowering barriers to entry to new markets and the cost of acquiring new customers

4. Alternative channels of communication to subscribers

5. Improve company image

6. Gaining a competitive advantage

7. Potential for increased customer knowledge.

According to Buchari, the quality of E-Service is determined by consumers, all assessments are good from service excellence to the quality of E-Service offered (Corbu et al. 2020). Meanwhile, based on the content analysis conducted by Yang (2003), there are 14 service quality dimension points, namely Responsiveness; Credibility; Ease of use; Reliability; Convenience; Communication; Access; Competence; Courtesy; Personalization; Continuous improvement; security/privacy; and aesthetics.

\section{Methods}

The type of research used in this research is qualitative research with a descriptive approach. Qualitative research is collecting data in a natural setting to interpret the phenomena that occur where the researcher is the key instrument, sampling of data sources is carried out purposively and snowballing, collection techniques are triangulation (combined), data analysis is inductive/qualitative, and research results Qualitative research emphasizes meaning rather than generalization(Setiawan 2018).

\section{Data Collection Techniques Data}

Collection techniques are the most important step in a study, where the main purpose of a study is to obtain data. According to Anggito and Setiawan (2018), there are many ways 
to be able to conduct a qualitative research method. One of them is observation or observation. The research conducted in this study are as follows:

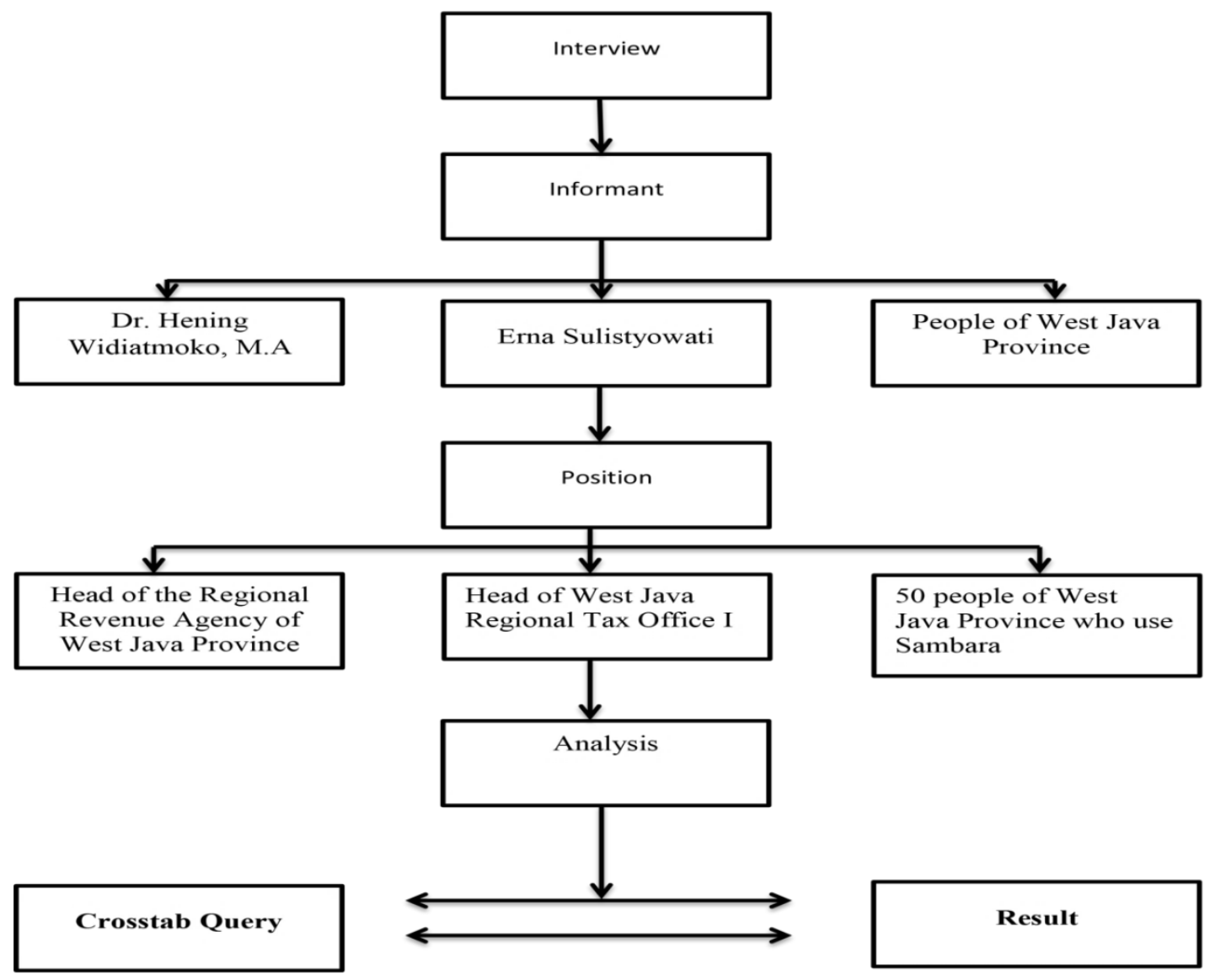

\section{Data Analysis Techniques Data}

Analysis techniques in qualitative research make data objectivity an instrument by providing broad opportunities for objects to convey information. Data analysis is more directed at organizing a finding which then constructs the findings into units that can be managed into important information (Pranata, 2019). From this analysis, conclusions will then be obtained on the object of research, so that it is useful in strengthening data in the research being conducted. One of the computer programs that can be used is the latest Nvivo application version 12(Hamid et al. 2002).

\section{Results and Discussion}

\section{Efficiency}

e-Government and e-Public Services have long been implemented in various provinces, including in West Java Province. Based on the results of the Provincial Level eGovernment Indonesia conducted by the Ministry of Communication and Information 
Technology, it was identified that at the start of the 2012 assessment West Java Province occupied the first position while in 2015 it fell to the second position after DKI Jakarta Province (Dhaou and Renard 2017). West Java Province has 3 (three) superior public service innovations based on Information and Communication Technology (ICT), namely the first, online tax service innovation (Sambara Application), second about innovation in digital coffee seed distribution (Sibulubabeh), and third about the program economic empowerment of Islamic boarding schools (OPOP).

The SAMBARA application (West Java Mobile Samsat) was first launched in 2017 because the management of the West Java Motor Vehicle Tax Payment service was constrained by the long distance of Samsa's physical services from residents' settlements and workplaces due to the location and geographical conditions of West Java. The limited time to pay taxes and the long-distance traveled have resulted in low public interest in paying motor vehicle taxes (Accessed from tuxedovation. inovasi.it bang.kemendagri.go.id on 20 June 2021 at $20.30 \mathrm{WIB})$.

This innovation helps create public services with an agile government model because it increases the convenience, speed, practicality, and accuracy of motor vehicle tax services. With the SAMBARA application, people can pay taxes anywhere and anytime as long as an internet network is available.

Figure 1.

SAMBARA Application Main Menu

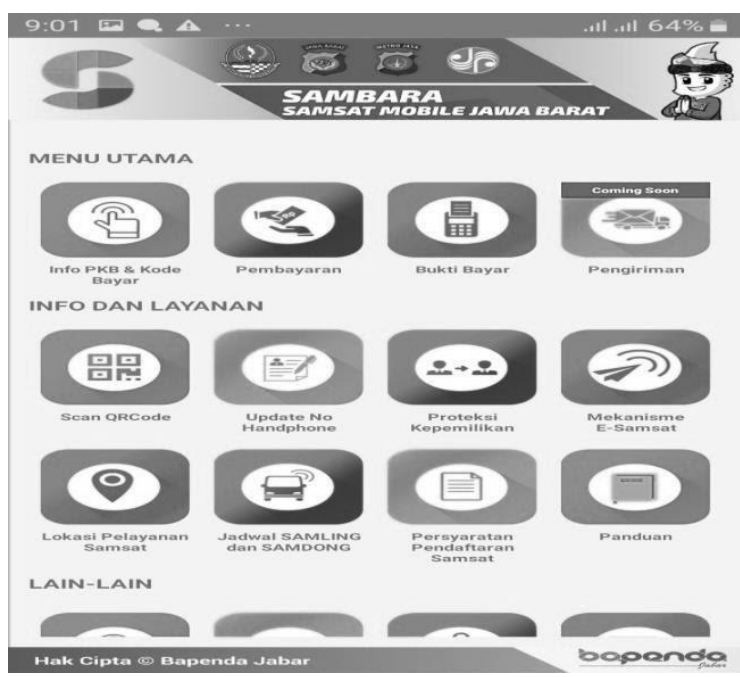

Source: Play Store 2021 
On the main menu of the Sambara application, there is a novelty of SAMBARA in the availability of various digital PKB service features, such as vehicle brand, model, year of vehicle issuance, color, frame number, engine number, amount of PKB, amount of PKB fines, SWDKLLJ, PNPB STNK, tax date the due date must be paid, owned by how much, to block the vehicle, plus various updates to the latest information on other Samsat services.

\section{Figure 2.}

\section{PKB Info}

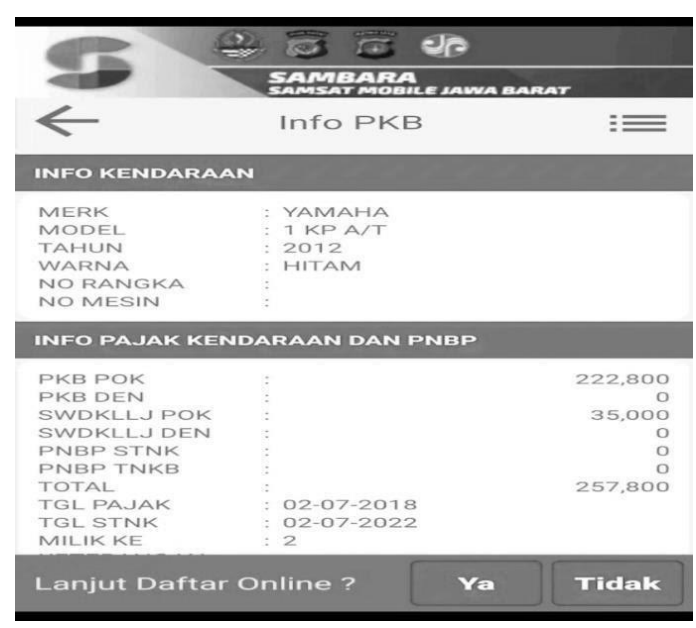

Source: play store 2021

In Sambara Version 3, there is an update in the form of a news page related to motor vehicle taxes in West Java Province, a new FAQ menu about frequently asked questions related to Sambara, information on the amount of PKB discounts obtained (in the framework of the Triple Untung Plus program), the addition of Tokopedia, Kaspro, and Indomaret in the payment menu complements the pre-existing payment methods, namely bank bjb, and Bank Mandiri.

\section{Figure 3.}

\section{SAMBARA Application Payment Method}

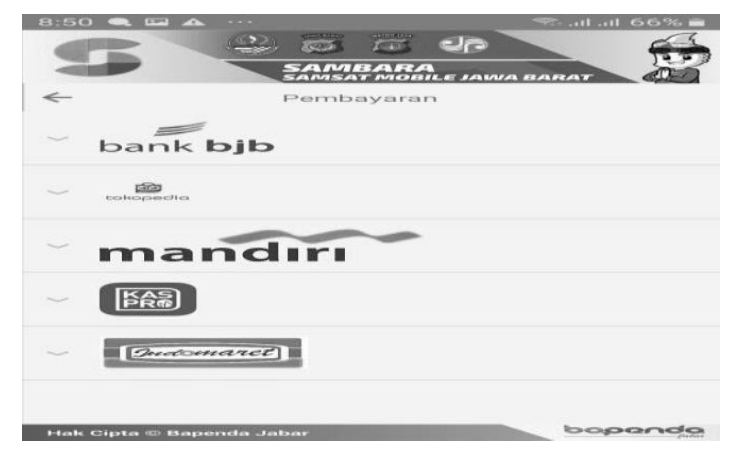

Source: play store 2021 
The existence of this application increases public interest in paying taxes because it is very efficient, namely no need to leave the house and no need to queue. The payment method is also very easy, you can choose according to the bank used or choose to pay at Indomaret, Tokopedia, or Kaspro.

Trust

Table 1.

Descriptive Analysis

\begin{tabular}{|lll|}
\hline & & \\
\hline Information Quality & $83.27 \%$ & Agree \\
\hline System Quality & $82.89 \%$ & Agree \\
\hline Services Quality & $83.18 \%$ & Agree \\
\hline User Satisfaction & $83.52 \%$ & Agree \\
\hline
\end{tabular}

Source: Processed Data by (Armeliadinda and Azis 2020)

Based on (Armeliadinda \& Azis, 2020), the table above shows that all variables in the study are included in the category agreement. Categories are obtained by grouping the total value divided by five measurement scales so that a range of values is obtained by $16 \%$. With that obtained a range of values of $20 \%-36 \%$ : strongly disagree, $36 \%-52 \%$ : disagree, $52 \%-68 \%$ : neutral, $68 \%-84 \%$ : agree, and $84 \%-100 \%$ : strongly agree. This means that the value of information quality, system quality, service quality, and user satisfaction in West Java can be said to be good/agree (Armeliadinda and Azis 2020).

The descriptive analysis above proves that the community believes and agrees with the innovation of the SAMBARA application, which can make it easier for people to pay taxes. West Java Province motor vehicle tax payment data shows that PKB receipts through the SAMBARA innovation in 2018 were 181,383 vehicles, worth Rp. 109,306,859,300,-. In 2019 it increased significantly to 545,652 vehicles, worth Rp. 406.620,726,100, - or an increase of $300.83 \%$ from 2018. It is also proved that public interest in paying taxes has increased with the SAMBARA application. 


\section{Reliability}

Reliability here means suitability and speed in accessing, using, and receiving services from the site.

Figure 4.

\section{SAMBARA App User Reviews}

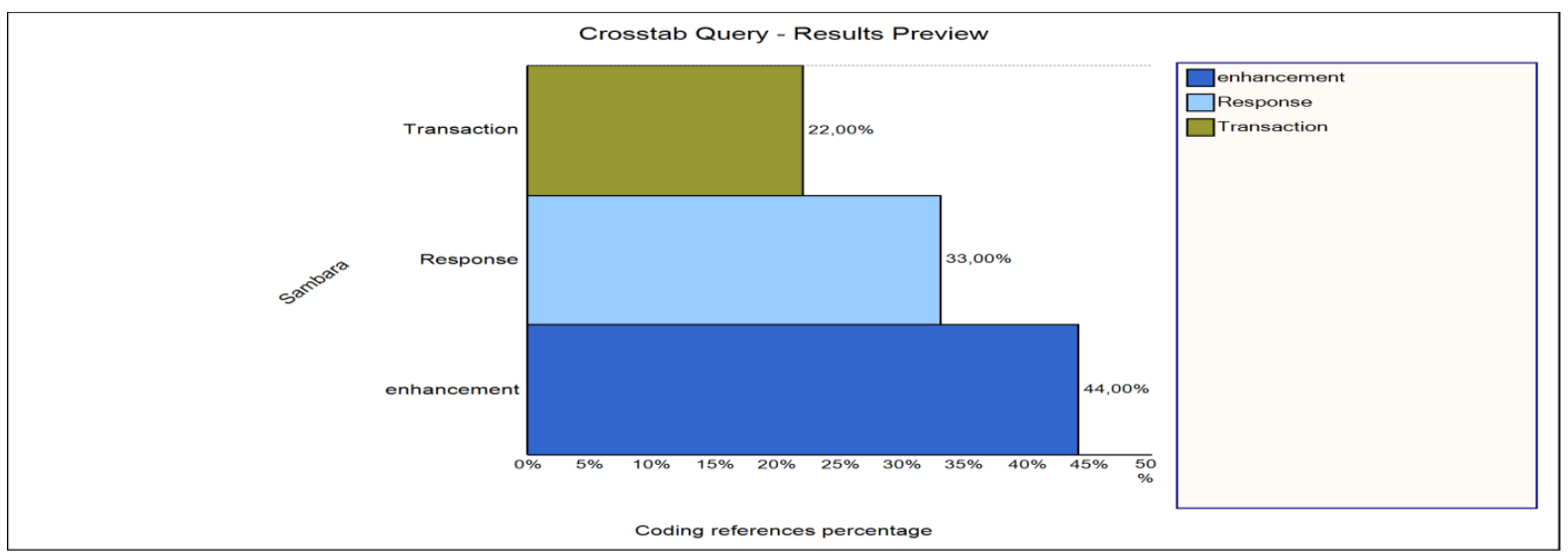

Source: play store 2021

The results of the reviews that have been obtained, the researchers found several problems or obstacles from the application of information, systems, and services for the SAMBARA application, including:

1. In the transaction system in the SAMBARA application, there are still obstacles, so the transaction cannot be processed.

2. The response from the SAMBARA application service is still fairly slow in response.

3. The app still needs UX/UI improvement

Every mobile application must have quality in operation, the quality of the application will make consumers feel facilitated by the features in the application(Setyawan and Adiwidjaja 2013). Therefore, a good application quality can increase user satisfaction and the number of users of the application itself. However, in this indicator, the SAMBARA application is still lacking in suitability and speed in accessing, using, and receiving services from the site. The problem with this application is that it is repaired too often and the service response is slow, which makes people wait too long. On this indicator, the authors suggest for the West Java provincial government to make overall improvements both in terms of service and UX/UI quality so that public satisfaction with the SAMBARA application increases. 


\section{Conclusion}

Based on the indicators that the author has used to analyze the e-Public Service Design in realizing Agile Government in West Java Province (Case Study of the SAMBARA Application for Online Tax Services in West Java), the authors conclude that:

1. The existence of this application increases public interest in paying taxes because it is very efficient, namely no need to leave the house and no need to queue. This innovation helps create public services with an agile government model because it increases the convenience, speed, practicality and accuracy of motor vehicle tax services. With the SAMBARA application, people can pay taxes anywhere and anytime as long as an internet network is available.

2. The descriptive analysis above proves that the community believes and agrees with the innovation of the SAMBARA application, which can make it easier for people to pay taxes. West Java Province motor vehicle tax payment data shows that the number of taxpayers increases after the launching of SAMBARA application. It is also proved that public interest in paying taxes has increased with the SAMBARA application.

3. However, the SAMBARA application is still lacking in suitability and speed in accessing, using, and receiving services from the site. The problem with this application is that it is repaired too often and the service response is slow, which makes people wait too long. It can be the advice for the West Java Government to improve the quality of the SAMBARA application.

4. The quality of Customer Service on the SAMBARA application is fairly good and helps the community in using the application.

The four indicators that have been used by the author can conclude that e-Public Service in terms of online tax services using the SAMBARA application in West Java is a great e-Public Service design in realizing Agile Government.

\section{References}

\section{Books}

Ati, Sri, Nurdien, Kistanto, and Amin Taufik. 2014. "Pengantar Konsep Informasi, Data, Dan Pengetahuan." Universitas Terbuka 230. 
Bartakova, G. P., J. Brtkova, K. Gubiniova, and M. Hitka. 2017. “Actual Trends in the Recruitment Process at Small and Medium-Sized Enterprises with the Use of Social Networking." Economic Annals-XXI.

\section{Journal article}

Diki Suherman. 2019. “Penyelenggaraan E-Government Di Kabupaten Bandung Sebagai Upaya Meningkatkan Kualitas Pelayanan Publik " Angewandte Chemie International Edition, 6(11), 951-952. 12(2):15-39.

Armeliadinda, and Elvira Azis. 2020. “Pengaruh Kualitas Informasi, Kualitas Sistem, Kualitas Layanan Terhadap Kepuasan Pengguna Aplikasi Pajak (Studi Kasus Pada Aplikasi SAMBARA Di Jawa Barat)." Jurnal of E-Proceeding of Management 7(2):2406-15.

Atthahara, Haura. 2018. “Inovasi Pelayanan Publik Berbasis E-Government: Studi Kasus Aplikasi Ogan Lopian Dinas Komunikasi Dan Informatika Di Kabupaten Purwakarta." Jurnal Politikom Indonesiana 3(1):66-77.

Dan, Analisis, Perancangan E-goverment Dalam, Dede Abdurahman, and Tri Ferga Prasetyo. 2018. “( Studi Kasus: Desa Tenjo Layar Dan Desa Tanjung Sari Majalengka ).” 05(01):246-55.

Hamid, Abdul, Program Studi, Ilmu Administrasi, Universitas Sultan, and Ageng Tirtayasa. 2002. “Aplikasi E Government Dan Dampaknya Studi Kasus Kabupaten Sragen.” 119.

Pada, Implementasi E-service, Organisasi Publik, D. I. Bidang, Pelayanan Publik, and R. Ahmad Buchari. 2016. “ABSTRAK. Penelitian Ini Dilakukan Karena Tuntutan Masyarakat Yang Sangat Besar Dalam Penyediaan Pelayanan Yang Memberikan Informasi Sesuai Dengan Kebutuhan Masyarakat. Untuk Menjawab Kebutuhan Tersebut Pemerintah Menggunakan Teknlogi Informasi Dan Komunik." 18(3):235-39.

\section{Journal article with DOI}

Amalia, Shafiera. 2020. “Melalui Pandemi Dengan Organisasi Dan Kebijakan Publik Yang Agile." Jurnal Wacana Kinerja: Kajian Praktis-Akademis Kinerja Dan Administrasi Pelayanan Publik 23(1):2018-21. doi: 10.31845/jwk.v23i1.678.

Bahruni, Siti Mahzurah, Marlita Mat Yusof, Siti Noraini Mohd Tobi, Ramita Abdul Rahim, and Murni Zarina Mohd Razali. 2018. “Continuance Intention of E-Government's Applications Adoption - The Moderating Effect of Trust." Proceedings of the 31st 
International Business Information Management Association Conference, IBIMA 2018: Innovation Management and Education Excellence through Vision 2020 2019:5865-76. doi: 10.5171/2019.409607.

B. Mokone, Christopher, Oduronke T. Eyitayo, and Audrey Masizana- Katongo. 2018. "Critical Success Factors for E-Government Projects: The Case of Botswana." Journal of E-Government Studies and Best Practices 2018:1-14. doi: 10.5171/2018.335906.

Corbu, N., A. Bârgăoanu, R. Buturoiu, and O. Ştefăniţă. 2020. “Does Fake News Lead to More Engaging Effects on Social Media? Evidence from Romania." Communications. doi: 10.1515/commun-2019-0152.

Dhaou, Soumaya I. Be., and Laurent Renard. 2017. “Categorization of E-Government Capabilities: Lessons Learned from a Canadian Public Organization." Proceedings of the 29th International Business Information Management Association Conference - Education Excellence and Innovation Management through Vision 2020: From Regional Development Sustainability to Global Economic Growth 2017:3929-41. doi: 10.5171/2017.

Joseph, Bwalya Kelvin. 2017. “Determining Factors Influencing E-Government Development in the Developing World: A Case Study of Zambia." Journal of E-Government Studies and Best Practices 2017:1-16. doi: 10.5171/2017.143795.

Mualidin, Isnaini. 2017. “Implementasi New Public Management ( Npm ) dalam Pelayanan Working Paper 2015 Implementasi New Public Management ( Npm ) dalam Pelayanan Perizinan di Dinas Perizinan Kota Yogyakarta Isnaini Muallidin Dosen Ilmu Pemerintahan Universitas Muhammadiyah Yogyak." (October). doi: 10.13140/RG.2.2.33461.17128.

Ramdani, Ari. 2020. “Analisis Deskriptif Terhadap Inovasi Layanan Aplikasi Sambara (Samsat Mobile Jawa Barat)." Jurnal Academia Praja 3(01):37-43. doi: 10.36859/jap.v3i01.141.

Reid, B. E. 2020. “Internet Architecture and Disability.” Indiana Law Journal 95(2):591-647.

Setiawan, Daryanto. 2018. “Dampak Perkembangan Teknologi Informasi Dan Komunikasi Terhadap Budaya." JURNAL SIMBOLIKA: Research and Learning in Communication Study 4(1):62. doi: 10.31289/simbollika.v4i1.1474. 
Setyawan, Dody, and Ignatius Adiwidjaja. 2013. “Strategi Meningkatkan Kesadaran Politik Dan Menolak Money Politic Pemilih Pemula Pada Pilkada Kota Malang." Jurnal Reformasi 3(2):90-95. 